\title{
Två- och flerspråkighet: Ett samtal om forskningsinriktningens uppkomst och konsolidering i Sverige
}

\author{
Av LINUS SALÖ, KENNETH HYLTENSTAM, \\ CHRISTOPHER STROUD \& DAVID KARLANDER
}

\begin{abstract}
Salö,Linus, linus.salo@biling.su.se, Associate Professor, Centre for Research on Bilingualism, Stockholm University, and Researcher, Division of History of Science, Technology and Environment, KTH Royal Institute of Technology; Hyltenstam, Kenneth, kenneth.hyltenstam@biling. su.se, Professor emeritus, Centre for Research on Bilingualism, Stockholm University; Stroud, Christopher, christopher.stroud@biling.su.se, Professor, Centre for Research on Bilingualism, Stockholm University, and Centre for Multilingualism and Diversities Research, University of the Western Cape; Karlander, David, dakar@hku.hk, PhD, Society of Fellows in the Humanities, The University of Hong Kong: "Bilingualism and multilingualism: A conversation about the rise and consolidation of a research area in Sweden." Språk och stil NF 31:1, 2021, pp. 13-43.

This article presents an edited conversation between Kenneth Hyltenstam, Christopher Stroud, Linus Salö and David Karlander. Its main topic is the rise and consolidation of bilingualism research/multilingualism research as a demarcated subject area in Swedish academe. The article delves into this history via the professional, scholarly trajectories of Hyltenstam and Stroud. By mapping and discussing their involvement in the field of bilingualism/multilingualism, the article offers analytical perspectives on the formation of the field, and on the general atmosphere surrounding this process. The account focuses on past and current research themes, institutional settings and modes of knowledge exchange. The creation of the Centre for Research on Bilingualism at Stockholm University in the 1980s emerges as a significant event in the evolving account of the research area. The conversation also makes clear that the history of bi/multilingualism research encompasses a variety of agents and interests. The subject area maintains mutable connections to numerous other scientific disciplines and is susceptible to various forms of intellectual influence. It has likewise been shaped in relation to various scholarly and societal values and concerns. By clarifying some of these dynamics, the article contributes to the yet-to-be-written history of bi/multilingualism research. It also comments on conversation as a scholarly method, and clarifies the scope and strength of its claims.
\end{abstract}

Keywords: bilingualism, multilingualism, history of linguistics, sociology of science, institutional and disciplinary formation. 


\section{Två- och flerspråkighet - ett bidrag till historieskrivningen}

Under senare år har begreppet flerspråkighet blivit föremål för ökat intresse, såväl i det offentliga samtalet som i akademiska sammanhang. De två formerna av uppmärksamhet hänger onekligen samman, men i det följande står det senare intresset i blickfånget. Vid universitet och högskolor har termen flerspråkighet synliggjorts i namn på institutioner och forskarskolor, i benämningar på lektors- och professorstjänster, i form av teman för vetenskapliga konferenser och forskningsprojekt. Det skrivs avhandlingar och ges universitetskurser om flerspråkighet. Det produceras vetenskapliga arbeten, läromedel och rapporter som på ett eller annat sätt intresserar sig för ämnet. Allt detta är skeenden $i$ en längre utveckling. Genom vårt bidrag till detta temanummer vill vi anlägga några historiska perspektiv på ämnet flerspråkighet och dess tillblivelse. Vi hoppas kunna bidra till en bättre förståelse för forskningsinriktningens ursprung, utvecklingslinjer och sociala inbäddning. Vi närmar oss således inte flerspråkighet som ett språkligt fenomen, utan i första hand som ett kunskapsintresse, vilket tagit form under specifika samhälleliga och historiska betingelser.

Vårt ärende är att lämna ett bidrag till flerspråkighetsforskningens utvecklingshistoria genom att erbjuda erfarenhetsbaserade inblickar i det historiska klimat i vilket inriktningen utvecklats. En sådan sociologisk ansats har föreslagits av exempelvis Konrad Koerner', som betonat att vetenskapshistoriska undersökningar av språkvetenskapen bör eftersträva att »återge så mycket som möjligt av det allmänna klimat» i vilket en viss forskningsinriktning eller teoribildning vuxit fram. Ett bidrag av detta slag, anser vi, kan bana väg för en reflexiv förståelse ${ }^{2}$ för vad flerspråkighet är, vilket sannolikt är av värde för forskningsinriktningens fortsatta utveckling. Vi föresätter oss däremot inte att skriva en uttömmande historik över forskning om flerspråkighet. Detta vore en alltför omfattande uppgift, inte minst då en sådan historieskrivning ännu endast omfattar ett fåtal bidrag. ${ }^{3}$ Snarare försöker vi förse ett sådant företag

\footnotetext{
${ }^{1}$ Koerner, Toward a History of American Linguistics (2002 s. 169, vår översättning). Se även Karlander, The linguistic prerequisites for cultural analysis (2018).

2 Wacquant, Towards a reflexive sociology (1989).

${ }^{3}$ Se bidrag i Flerspråkighet - en forskningsöversikt, red. av Hyltenstam, m.fl. (2012), Heller, Bilingualism as ideology and practice (2007), Levelt, A History of Psycholinguistics (2013), Salö, Invandrarutredningen och 1970-talets språkideologiska omvälvningar (2020), Salö \& Karlander, The travels of semilingualism (u.u.).
} 
med stoff och perspektiv. Det är alltså fråga om ett bidrag till historiseringen av flerspråkighet som forskningsintresse, främst i Sverige men också med internationella utblickar.

\section{Samtalsformatets möjligheter och begränsningar}

Vårt bidrag består av ett tematiskt strukturerat, ämneshistoriskt hållet samtal mellan de fyra författarna. ${ }^{4}$ Den text som presenteras nedan härrör från en transkriberad inspelning av detta samtal, som efterbehandlats och försetts med en förklarande notapparat. Vi hoppas att vårt angreppssätt kan bereda plats åt personliga perspektiv och synpunkter i högre grad än vad exempelvis institutionellt eller metateoretiskt orienterade historieskrivningar kan tillåta sig att göra. ${ }^{5}$

Det redigerade akademiska samtalet är en vedertagen genre. ${ }^{6}$ En rad vetenskapshistoriskt intresserade språkvetare har utforskat denna möjlighet till historieskrivning via intervjuer, samtal och retrospektiva reflektioner. ${ }^{7}$ Vi går till väga på ett snarlikt sätt. Vi menar att den erbjuder en rimlig ingång till att undersöka frågor om vårt forskningsområdes tillkomst och historiska förändringar, utan att för den sakens skull erbjuda entydiga svar. Hyltenstam och Stroud har, på sina respektive sätt, starkt bidragit till denna utveckling, både i Sverige och internationellt. Inte minst av detta skäl är det begripligt att deras erfarenheter, ståndpunkter och reflektioner beretts utrymme. Det följer av detta att bidraget delar de villkor som präglar alla betraktelser »tagna ur hästens mun», i den meningen att de återger skeenden och tillstånd via individers positionerade erfarenheter, synsätt och uppfattningar. ${ }^{8}$ Det rör sig alltså om personliga betraktelser och analyser - inte en komplett historieskrivning.

${ }^{4}$ Samtalet ägde rum den 28 januari 2020. Hyltenstam, Karlander och Salö möttes i Sättraby och Stroud deltog på videolänk från Kapstaden.

5 T.ex. Malmberg, Histoire de la linguistique de Sumer à Saussure (1991), Heller (2007), Levelt (2013).

${ }^{6}$ T.ex. Bayly m.fl. AHR Conversation: On transnational history (2006), Faust m.fl. Interchange: The practice of history (2003), Wacquant (1989).

7 T.ex. Harris, The Linguistics Wars (1993), Huck \& Goldsmith, Ideology and Linguistic Theory (1995), The Early Days of Sociolinguistics, red. av Christina Bratt Paulston \& Richard Tucker (2010).

${ }^{8}$ För liknande exempel, se Hansegård, Den norrbottenfinska språkfrågan (1990). Se även Inger Lindbergs föredrag Min andraspråksresa vid konferensen Vadan och varthän? Dåtid, nutid och framtid för svenska i ett andraspråksperspektiv, Stockholm, 16 januari 2020. 
Något bör sägas om hur vi ser på formatets möjligheter att säga något om flerspråkighetsforskning som forskningsinriktning. Som ska framgå handlar en betydande del av samtalet om den verksamhet som bedrivits vid Centrum för tvåspråkighetsforskning och dess förelöpare, som sedan 1981 varit förlagt vid Stockholms universitet och som är eller har varit de fyra samtalsdeltagarnas gemensamma arbetsplats. Att denna miljö fått en framflyttad position i samtalet betyder inte att den varit den enda aktören i det mångröstade fält som intresserat sig för flerspråkighet, och som med tiden kommit att innefatta allt fler frågeställningar och aktörer. ${ }^{9}$ Onekligen bedrevs flerspråkighetsintresserad forskning innan tvåspråkighetsforskningen institutionaliserades. Den forskning som sedermera bedrivits vid Centrum för tvåspråkighetsforskning har varken utgjort eller ens speglat forskningsinriktningen i sin helhet. Ändå är miljöns centrala plats i samtalet både rimlig och berättigad, inte minst givet bidragets och specialnumrets tematik. Generellt är det av intresse att analysera den roll en formell institutionsbildning kan ha för ett forskningsområdes inriktning och status. Vi menar även att Centrum för tvåspråkighetsforskning kan betraktas som en tidig och viktig del av flerspråkighetsforskningen och det intellektuella och samhälleliga klimat som omgivit den. Sedan 1980-talet har denna avgränsade forskningsmiljö haft en betydande inverkan på flerspråkighetsforskningens utveckling, då den givit forskningsinriktningen stadga och fastare konturer. Genom att hänvisa till denna verksamhets historia får vi alltså goda möjligheter att belysa det innehåll som kunskapsintresset flerspråkighet kommit att inrymma.

\section{Samtalet och dess deltagare}

Vårt samtal tar avstamp i en begreppsdiskussion för att sedan övergå till frågan om flerspråkighetsforskningens utvecklingslinjer. Vi behandlar bland annat tvåspråkighetsforskningens disciplinära och intellektuella förhållande till allmän lingvistik och annan språkvetenskap, samt dess förhållande till ämnesområden som psykologi, utbildningsvetenskap, utvecklingsstudier, internationell migration och etniska relationer. Ett annat tema är tvåspråkighetsforskningens mer tillämpade sida, vilken kommit till uttryck dels i utredningsarbeten

\footnotetext{
${ }^{9}$ Se t.ex. Flerspråkighet, litteracitet och multimodalitet, red. av Wedin \& Hedman (2013), Hyltenstam, Axelsson \& Lindberg (2012), Svenska som andraspråk, red. av Kenneth Hyltenstam \& Inger Lindberg (2013).
} 
och policyrelaterade uppdrag, dels i relation till skolämnen som svenska som andraspråk och modersmål.

Vårt samtal ger vid handen att flerspråkighet som forskningsinriktning länge varit mångdisciplinär och samhällstillvänd, även om den likt andra forskningsinriktningar både expanderat och specialiserats över tid. Inriktningen har rört sig framåt genom en kombination av samhällsengagemang och kunskapsavancemang, som förstärkt och varit beroende av varandra. Centrum för tvåspråkighetsforsknings historiska värv exemplifierar därmed väl den dubbelriktade relationen mellan forskning och samhälle. Det allmänna klimat som omgärdat flerspråkighet som forskningsinriktning har inte bara möjliggjort enhetens verksamhet. Enhetens verksamhet har också påverkat detta klimat. Innan vi går vidare till detta bör emellertid samtalsdeltagarna presenteras.

Kenneth Hyltenstam (f. 1945) disputerade 1978 i lingvistik vid Lunds universitet och blev där samma år forskarassistent i ämnet. Han tillträdde 1981 en docenttjänst vid Stockholms universitet med tilläggsuppdrag som föreståndare för den nybildade Avdelningen för tvåspråkighetsforskning vid Institutionen för lingvistik, som 1988 övergick i Centrum för tvåspråkighetsforskning. 1992 tillträdde han där en nyinrättad professur i tvåspråkighetsforskning och fortsatte som Centrets ${ }^{10}$ föreståndare fram till 2007, ett uppdrag som han också innehade 2012-2013. Han har varit gästprofessor vid Jyväskylä universitet (1989), University of Hawai'i at Mānoa, Honolulu (1992) och Universidad Central de Venezuela, Caracas (1998). Sedan 2015 är han professor emeritus.

Christopher Stroud (f. 1953) påbörjade sin forskarutbildning i lingvistik vid Lunds universitet, och disputerade i samma ämne 1991 vid Stockholms universitet på en avhandling om språkdöd, kodväxling och litteracitet i Papua Nya Guinea. Förutom att han har varit verksam vid Stockholms universitet, Centrum för tvåspråkighetsforskning sedan 1986, har han även arbetat vid universitet i Singapore, Moçambique och Sydafrika. Hans forskning innefattar språkkontakts- och flerspråkighetsproblematik, särskilt språkideologiska och språkpolitiska utbildnings- och utvecklingsfrågor. Han arbetar just nu med att färdigställa en bok om språkligt medborgarskap och dekolonialitet med titeln Subsequent subjectivities: Decolonial dialogues on linguistic citizenship.

Linus Salö (f. 1980) blev fil.dr i tvåspråkighet 2016, handledd av Hyltenstam och Stroud. Han är numera docent och universitetslektor vid Centrum

${ }^{10}$ D.v.s. Centrum för tvåspråkighetsforskning. Denna mer informella benämning förekommer även nedan. 
för tvåspråkighetsforskning, samt forskare vid Kungliga Tekniska högskolan i Stockholm (inom projektet Making Universities Matter, Vinnova).

David Karlander (f. 1987) disputerade 2017 i tvåspråkighet vid Stockholms universitet. Hans avhandlingsprojekt handleddes av Hyltenstam, Stroud och Tomas Riad. Sedan 2018 är han Society of Fellows postdoctoral fellow vid University of Hong Kong.

\section{Ett samtal om bakgrunden till dagens flerspråkighetsforskning}

LS: Det temanummer som det här samtalet ingår i handlar om flerspråkighet, men vi som sitter här har anknytning till ämnet tvåspråkighet. Så vi kanske ska bena ut det: hur ser ni på relationen mellan »tvåspråkighet» och »flerspråkighet»? Är det olika saker eller är termerna synonymer?

CS: Ja, det är olika etiketter på sådant som har samma intellektuella innehåll. Men jag har en känsla av att det är någonting som diskuteras hela tiden på något sätt. När Senter for flerspråklighet skulle bildas vid Universitet i Oslo fördes det diskussioner om det skulle vara flerspråkighet eller tvåspråkighet $\mathrm{i}$ namnet. En annan diskussion är den om huruvida flerspråkighet är något mer samhällsinriktat och tvåspråkighet kanske appellerar mer till psykolingvistiskt eller kognitivt inriktade forskare.

KH: Ja, det är väl karakteristiskt att den ledande tidskriften på området med inriktning mot psyko- och neurolingvistik heter Bilingualism: Language and Cognition, medan tidskrifter som Journal of Multilingual and Multicultural Development och International Journal of Multilingualism och andra med multilingualism i namnet har ett bredare, ofta sociolingvistiskt, språkpolitiskt eller pedagogiskt innehåll.

CS: Och så finns det en tidsdimension. Åtminstone fram till 70- och 80-talet var det mest tvåspråkighet det talades om. Om man talade om en individ som flerspråkig var det i så fall någon som behärskade fler än två språk, man gjorde alltså en distinktion mellan tvåspråkiga och flerspråkiga personer eller såg tvåspråkighet som ett specialfall av flerspråkighet. ${ }^{11}$ Hos till exempel Haugen och Fishman så var tvåspråkighet termen. Det här med flerspråkighet har kommit

${ }^{11}$ Se t.ex. Stedje \& af Trampe, Förord. Språk, individer och grupper - en översikt av tvåspråkighetens huvudfrågor (1979). 
till mer på senare tid. Kanske i analogi med multiculturalism. Så jag får en känsla av att om man ska prata om kanoniska begrepp och texter så är det främst termen tvåspråkighet som gäller, eller som länge gällde i varje fall. Från typ Haugen ${ }^{12}$ och Weinreich ${ }^{13}$ till nyare verk, som Hellers antologi ${ }^{14}$. Sedan kan det också vara så att tvåspråkighet är ett typiskt nordfenomen medan flerspråkighet är ett sydfenomen.

KH: Jag har samma uppfattning som du - det finns en historisk eller en diakron aspekt på det. Tidigare var det mest tal om tvåspråkighet och sedan har det successivt blivit mer och mer tal om flerspråkighet. Begreppet flerspråkighet har nog alltmer kommit att appliceras på sociolingvistiska frågor medan tvåspråkighet i stor utsträckning har hållits kvar för de kognitiva, psykolingvistiska och individrelaterade frågorna. Det tyder ju på att termerna $\mathrm{i}$ stor utsträckning använts synonymt, kanske under en övergångsperiod. Det kan vara svårt att dra tydliga skiljelinjer mellan dem.

DK: Så hur robust är den disciplinära skillnaden egentligen? Är den också i uppluckring?

KH: Jag tror att den kan vara i uppluckring. Jag tror att det har uppstått en disciplinär uppdelning under resans gång, men jag tror inte att den längre är så tydlig eller att den kommer att leva kvar. Forskare som inlett sin bana inom tvåspråkighetsämnet återfinns idag inom en rad andra institutioner och forskningsinriktningar. Det såg man ju till exempel på konferensen som Nationellt centrum för svenska som andraspråk anordnade med anledning av Inger Lindbergs och Monica Axelssons avtackning. ${ }^{15}$ I programmet framträdde professorer i en rad olika ämnen och alla utom en var doktorer i tvåspråkighet från Centret. Jag tänker på Inger Lindberg, professor i tvåspråkighet med inriktning på andraspråksinlärning, Monica Axelsson, professor i tvåspråkighet med inriktning på svenska som andraspråk, Päivi Juvonen, professor i svenska som andraspråk, Christina Hedman, professor i svenska som andraspråk med didaktisk inriktning, Tommaso Milani, professor i flerspråkighet och Åsa Wedin, professor i pedagogiskt arbete. ${ }^{16}$ Allt detta vittnar om hur flerspråkig-

\footnotetext{
${ }_{12}$ Haugen, Bilingualism in the Americas (1956).

13 Weinreich, Languages in Contact (1953).

14 Bilingualism: A Social Approach, red. av Heller (2007).

15 Konferensen Vadan och varthän? Se not 8.

${ }_{16}$ Doktorerade vid Centret: Lindberg, Axelsson och Hedman vid Institutionen för språkdidaktik, Stockholms universitet, Milani vid Institutionen för svenska språket, Göteborgs universitet, Wedin vid Akademin humaniora och medier, Högskolan i Dalarna. Juvonen (fil.dr lingvistik) arbetar vid Institutionen för svenska språket, Linnéuniversitetet, men verkade under en period vid Centret.
} 
hetsämnets utveckling hängt ihop med institutionell utbyggnad på flera universitet.

LS: Ja, den disciplinära glidningen har också en institutionell sida. Men är det kanske ändå inte lite oklart hur flerspråkighetsforskningens ämneshistoria relaterar till tvåspråkighetsforskningens ämneshistoria? Jag upplever det ibland som att det finns en idé om att flerspråkighetsforskning är ett helt nytt ämne.

CS: Jag tror att det är en profileringsstrategi. Det hänger väl delvis samman med den nya diskussionen om polylingualism, metrolingualism och translanguaging. Flerspråkighet funkar där men kanske inte tvåspråkighet. Det funkar sämre i den där mångfalden.

KH: Det här hänger ju ihop med det som har kallats the multilingual $t_{u r n}{ }^{17}$, hela den utvecklingen under de senaste trettio åren där språk inte ses som tydligt avgränsade från varann och att språk som fenomen snarare ses utifrån talarnas flerspråkiga och multimodala repertoarer. Att den svenska skolan sedan ett par decennier tillbaka använder flerspråkiga elever som teknisk term är nog också en spegling av den här teoretiska utvecklingen. Jag upplever också att särskilt sociolingvistiken som forskningsfält har blivit något som alltmer handlar om flerspråkighet.

LS: Verkligen. När man åker på Sociolinguistics Symposium eller en AILAkongress tycks mycket av innehållet på något sätt handla om flerspråkighet, superdiversitet - någonting ditåt. Det är närmast exotiskt när någon är där för att tala om språk och kön eller språk och klass. Så internationellt verkar hela det här kunskapsintresset ha sipprat tillbaka in i de gamla paradigmen och förändrat något. Och sådana forskare som Monica Heller, Ben Rampton, Jan Blommaert och andra som man numera betraktar som agendasättande inom sociolingvistiken har ju karriärer som knappast handlat om enspråkighetsfrågor.

DK: Ja, det finns förstås folk som sysslar med variationistisk sociolingvistik, men flerspråkighet är helt klart en pol att förhålla sig till, inte minst på ett teoretiskt plan. Det verkar vara något man tar i beaktande, även om man forskar om något mer traditionellt.

CS: Så är det nog.

DK: Samtidigt är det intressant att folk ofta knyter termen flerspråkighet till nyhet. Men i exempelvis ett tyskt sammanhang är Mehrsprachigkeit en term

17 The Multilingual Turn, red av May (2014), Meier, The multilingual turn as a critical movement in education (2017). 
som använts åtminstone sedan ett sekel tillbaka, i varje fall lika tidigt som Zweisprachigkeit eller Bilingualismus. ${ }^{18}$ Det finns kopplingar till den idéhistoriska bakgrunden som inte alltid tydliggörs i dagens diskussioner om flerspråkighet. I varje fall inte bland sociolingvister.

LS: Inte heller i Sverige är förstås glosan flerspråkighet ny. Jag har nyligen läst Berggrens Palmebiografi. ${ }^{19}$ Apropå Sveriges pluralistiska vändning under 70-talet är det spännande att tänka på Palmes bakgrund, att han kom från ett flerspråkigt hem och själv talade flera språk sedan barnsben. Det finns på tal om det ett Youtubeklipp där Palme säger »Det är en följd av att man växer upp i ett flerspråkigt hem [...] Det har lärt mig mycket om flyktingars villkor, om invandrares villkor. Jag har växt upp med det. $\rangle^{20}$ Så han använder ju termen flerspråkighet, som ju ofta sägs vara ett nutida modeord.

KH: I det sammanhanget associerar jag det till det flerspråkiga Centraleuropa. Som när Michel Paradis skrev om alla afasifall som finns beskrivna i litteraturen. ${ }^{21}$ Där är det ju många individer som är just flerspråkiga och då betyder det specifikt att det inte bara var två utan flera språk som var relevanta i sammanhanget, att det rådde en komplex språksituation. Palmes mamma hade ju för övrigt tysk-baltisk bakgrund.

DK: Vi kanske kunde fortsätta in i en svensk akademisk terräng. De betydelser som begreppen tvåspråkighet och flerspråkighet har fått verkar också höra samman med hur fältet utvecklats i ett svenskt sammanhang. Linus och jag har en idé om en slags historisk grand tour här. Det är kanske inte den mest behändiga ingången men: vilka perspektiv kan man ställa upp på två- eller flerspråkighetsforskningens början i Sverige?

KH: Det var nog först på 1970-talet som tvåspråkighet började uppfattas som ett eget forskningsområde i Sverige - och i de nordiska länderna. En viktig reflex av att utvecklingen tog fart då var att den första nordiska konferensen om tvåspråkighet hölls på Hanaholmen i Helsingfors, 1976. Fortsättningen, den andra konferensen i serien, hölls i Stockholm 1978. Det fanns förstås forskning om tvåspråkighet även tidigare på enskilda språkvetenskapliga, samhällsvetenskapliga och beteendevetenskapliga institutioner, men det var i och med denna plattform som man kunde tala om ett spirande fält. Man kan fundera på hur det såg ut när Centrum för tvåspråkighetsforskning vid Stockholms universitet,

\footnotetext{
18 T.ex. Hugentobler, Die mehrsprachige Schweiz (1928), Pötzl, Aphasie und mehrsprachigkeit (1930).

${ }^{19}$ Berggren, Underbara dagar framför oss (2010).

${ }^{20}$ Gäst hos Hagge, 1977.

${ }^{21}$ Readings in Aphasia in Bilinguals and Polyglots, red. av Paradis (1983).
} 
eller rättare sagt dess föregångare Avdelningen för tvåspråkighetsforskning, startade 1981. Vad fanns innan?

LS: Ja, vad fanns då? Och hur relaterar det till det som nu finns?

KH: Tvåspråkighet eller flerspråkighet uppfattas idag som ett väldigt brett forskningsområde i Sverige. En del av det som idag anses ingå uppfattades nog inte självklart som att det hörde dit på den tiden. Det stora fältet andraspråksinlärning uppfattades nog snarare som sidoordnat än inordnat i tvåspråkighetsforskningen. Samma sak kan sägas om översättningsvetenskap. De forskare som man då såg som typiska tvåspråkighetsforskare var sådana som skrev om tvåspråkighet i en skolkontext, som Nils Erik Hansegård ${ }^{22}$ och Tove SkutnabbKangas. ${ }^{23}$ Eller Magdalena Jaakkola som skrev om språkval, alltså tvåspråkighet $\mathrm{i}$ en social kontext.

\section{LS: Språkgränsen. ${ }^{24}$}

KH: Språkgränsen, ja. Det var en helt traditionell språkvalsundersökning av svenska och finska. I den andan arbetade också Henning Johansson, som undersökte samers behärskning av samiska i olika kontexter och i olika förmågor. ${ }^{25} \mathrm{Ja}$, sedan var det den här hansegårdska idén om halvspråkighet ${ }^{26}$ som triggade nordister eller sociolingvister som Bengt Loman ${ }^{27}$ att komma in i fältet. Men också Els Oksaar ${ }^{28}$ och Velta Rūķe-Draviņa ${ }^{29}$ som skrev om små barns tvåspråkiga utveckling. Sedan fanns det forskare inom psykologi i Stockholm. Stanislav Dornič och Edith Mägiste var tidigt ute med studier av språkprocessning och minnesfunktioner hos tvåspråkiga i respektive språk, med reaktionstidsmätningar, Strooptest och andra experimentella metoder. ${ }^{30}$

DK: Bertil Malmberg då? Han var väl din handledare, Kenneth?

KH: Ja, det stämmer. Bertil Malmberg hade en viss roll i sammanhanget. Han deltog i debatter och var en tidig förespråkare för modersmålsundervisning. Han skrev en hel del om språkinlärning och språkundervisning, ${ }^{31}$ men

22 Hansegård, Finskt i Tornedalen, en glömd minoritet (1966), Hansegård, Tvåspråkighet eller halvspråkighet? (1968).

${ }^{23}$ Skutnabb-Kangas, Om tvåspråkighet och skolframgång (1975).

24 Jaakkola, Språkgränsen (1973).

25 Johansson, Samernas språk och kultur (1975).

26 Hansegård (1968).

27 Språk och samhälle 2, red. av Loman (1974).

${ }_{28}$ Oksaar, Zum Spracherwerb des Kindes in zweisprachiger Umgebung (1970).

${ }^{29}$ Rūkse-Dravina, Mehrsprachigkeit im Vorschulalter (1967).

30 T.ex. Mägiste, Speed and Memory Performance in Bilinguals (1982), Dornič, The Bilingual's Performance (1978).

31 Malmberg, Språkinlärning (1971). 
hans egen forskning om vad som betraktades som tvåspråkighet på den tiden var inte omfattande. Det var väl främst uppsatsen Ett barn byter språk. ${ }^{32}$

CS: Den om det finska krigsbarnet.

KH: Ja, Malmberg hade ett finskt krigsbarn i sin familj som han studerade. Ja, det är ingen systematisk dokumentation utan mer vad han råkade höra enstaka exempel på hur barnet talade, på hur hon var kreativ med de två språken. Lite som klassikerna inom forskning om barns tidiga tvåspråkiga utveckling, Ronjat och Leopold, som kan ha varit förebilderna. ${ }^{33}$ Malmbergs inlägg om språkundervisning hade ofta också kopplingar till hans kärnintressen, den språkvetenskapliga strukturalismen och fonetiken.

LS: Du sa tidigare, Kenneth, att andraspråksinlärning och översättning inte betraktades som självklara delar av tvåspråkighetsforskningen.

KH: Ja, andraspråksforskning hade internationellt börjat etablera sig som eget forskningsområde mot slutet av 1960-talet och är ju fortfarande ett område med egna konferenser, egna tidskrifter och egna akademiska institutioner och tjänster. Det ses nog oftast fortfarande som särskiljt från tvåspråkighetsforskningen, samtidigt som de två går in i varandra. Detsamma gäller översättningsvetenskap med både tolkning och översättning. När jag själv kom in i fältet andraspråksinlärning var det inom den forskningsinriktning som i början av 1970-talet kallades interimspråksforskning. Mycket av den tidiga forskningen var inriktad på felanalys. Man tittade helt enkelt på vilka svårigheter inlärarna hade, vilka fel de gjorde och så vidare. Parallellt med trenden på andra ställen i Europa ${ }^{34}$ startades det några forskningsprojekt om inlärare med svenska som modersmål som lärde sig främmande språk, engelska i Lund till exempel, av Jan Svartvik och Stig Johansson. ${ }^{35}$

DK: Vad säger du då, Christopher? Delar du den här synen? Är det ett rimligt sätt att börja?

CS: Jag tycker det. Visst uppfattade man det på det här sättet. Sen fanns det en del internationella spår också. Jag tänker på hur man exempelvis läste en bok som Bilingualism in the Americas. ${ }^{36}$ Hos Haugen, Weinreich och andra fanns det också öppningar mot kontaktlingvistik, psykologi, pedagogik. ${ }^{37} \mathrm{Hau}-$

${ }^{32}$ Malmberg, Ett barn byter språk (1945).

33 Ronjat, Le développement du langage observé chez un enfant bilingue (1913), Leopold, Speech Development of a Bilingual Child (1939-1949).

${ }^{34}$ Se bidrag i Error Analysis, Contrastive Linguistics, and Second Language Learning, red. av Nickel \& Nehls (1981).

35 Papers in Contrastive Linguistics and Language Testing, red. av Johansson (1975).

36 Haugen (1956).

37 Weinreich (1953), Haugen (1956). 
gen intresserade sig ju för vad som hände med norskan i USA, alltså för språkbyte och språkbevarande. Sen fanns det väl också en del internationella kontakter. Jag minns till exempel att vi hade ett möte med Jim Cummins i Lund runt 1976 där han diskuterade tröskelhypotesen, sina idéer om »ytflyt» och »underliggande språkförmåga».

DK: För att zooma ut lite: är det alltså relevant att prata om en genomgripande förändring i fältet under 70-talet? Ni talar både om förelöpare och förnyelse, om brytningar och nya influenser. Vad mer var viktigt för den utvecklingen?

KH: Vi måste nämna den hetsiga mediedebatten om undervisningsmodeller som ägde rum vid slutet av 1970- och början av 1980-talet. Diskussionen handlade om huruvida man skulle ha modersmålsklasser eller sammansatta klasser. Språkundervisningsmodeller var kanske egentligen Tove SkutnabbKangas fokus. Hon argumenterade för att man borde satsa på modersmålsklasser, att man borde organisera undervisningen på ett sätt som skulle göra det möjligt för elever att säkra sin utveckling i minoritetsspråket innan svenskan gavs stort utrymme. Debatten blev också ihopkopplad med halvspråkighetsfrågan. I den debatt som uppkom där var Lars Henrik Ekstrand huvudmotståndaren. Han tyckte att man skulle ha sammansatta klasser så att eleverna så tidigt som möjligt fick stöd för sin utveckling både av svenskan och minoritetsspråket. Det konstiga var att diskussionen handlade just om det, men att många av dem som tog del i diskussionen i insändarspalter och liknande trodde att den handlade om huruvida man skulle ha modersmålsundervisning eller inte. Flera forskare påpekade att val av undervisningsmodell förmodligen hade mindre betydelse än den hetsiga debatten gjorde gällande ${ }^{38}$ och att debatten tog bort uppmärksamheten från majoriteten av »invandrareleverna», som det hette då, de 85 procent som inte undervisades i någon av modellerna. ${ }^{39}$

DK: Hur förhöll ni er till den tidiga utveckling som vi nu pratat om? Vilken roll spelade den för tvåspråkighetsforskningens institutionalisering under 80-talet?

KH: Ja, alltså, jag tror att en sådan sak som att Centrum för tvåspråkighetsforskning kom till stånd spelade en viktig roll i vidgningen av vad man menade med tvåspråkighet. I Stockholm fanns möjligen en större bredd än tidigare i hur man tolkade begreppet tvåspråkighet.

\footnotetext{
${ }^{38}$ Löfgren \& Ouvinen-Birgerstam, Försök med en tvåspråkig modell för undervisning av invandrarbarn (1980).

39 Tingbjörn, Skolan som resursförvaltare (1986).
} 
DK: Vad berodde det på?

$\mathrm{KH}$ : Ja, det var kanske bland annat en effekt av utformningen av de nordiska konferenserna om tvåspråkighet i Helsingfors och Stockholm som vi pratade om tidigare. Under åren 1979-1980 hade Stockholms universitets humanistiska fakultet diskuterat ett centrum för tvåspråkighetsforskning. Redan då var det en viss dragkamp. Det fanns ett intresse hos Tyska institutionen för att få till stånd en centrumbildning inriktad på översättningsvetenskap. Ganska omgående kom det en reaktion från Institutionen för lingvistik dit projektet Svenska som målspråk (SSM) med Åke Viberg och Björn Hammarberg var förlagt. Och de hävdade väl att det vore bättre att satsa på ett ämne som hade en stor samhällsrelevans i det samtida Sverige och så. I slutändan blev det en kompromiss, alltså ett centrum för tvåspråkighetsforskning, snarare än ett översättningscentrum eller ett andraspråkscentrum. När jag reflekterar över det nu så verkar det som om man tyckte att tvåspråkighet kunde fungera som en paraplyterm. Det kunde täcka in de andra två. När verksamheten väl startat, med mig som föreståndare då, arbetade jag själv för att hålla inriktningen så bred som det någonsin var möjligt.

CS: När vi ändå pratar om Centrets inriktning och räckvidd: de här böckerna som du, Kenneth, gav ut under 1980-talet, eller kanske till och med sent 70-tal. Först var det väl den som kom ut 1979, om kontrastiv analys och typologi? ${ }^{40}$ Och Språkmöte ${ }^{41}$ kom efter den.

KH: Ja, den första som kom 1979 var alltså Svenska i invandrarperspektiv. Den är ett så typiskt exempel för det jag sa innan om uppdelningen mellan andraspråksinlärning och tvåspråkighet. Jag tror inte att ordet tvåspråkighet står någonstans i den boken. Och därefter Språkmöte. Anledningen till att den fick heta Språkmöte var att den inte bara skulle täcka andraspråksinlärningsfrågorna utan också tolkning, alltså ditt bidrag där om tolkning, Christopher. Jag fick alltså hitta på en vidare titel och då började det ju närma sig tvåspråkighet.

CS: Ja, och sedan samtidigt var det väl Främmandespråksundervisning och översättning ${ }^{42}$ och sedan en samlingsvolym ${ }^{43}$ som var en konferensvolym från ett ASLA-möte om Nordens språk som målspråk 1983. Det hade kanske någon betydelse att det fanns en uppsättning texter som kunde bidra till att Centret fick en sådan inriktning som det fick.

40 Svenska i invandrarperspektiv, red. av Hyltenstam (1979).

${ }^{41}$ Språkmöte, red. av Hyltenstam (1981).

${ }^{42}$ Främmandespråksundervisning och översättarutbildning, red. av Hyltenstam (1981).

${ }_{43}$ Nordens språk som målspråk, red av Hyltenstam \& Maandi (1983). 
DK: Fanns det några andra saker som bidrog till det?

KH: En av de viktigaste bitarna var att vi fick till stånd en forskarutbildning i tvåspråkighet 1990. Det var ju vid den tiden då man började bli väldigt restriktiv med att ta in doktorander, och krävde att alla skulle vara finansierade med doktorandanställningar. Vi försökte vara så flexibla som möjligt när det gällde finansiering, och hittade finansiering på olika håll. Till exempel Margaret Obondo, som disputerade $1996,{ }^{44}$ hade från början sin finansiering från Svenska Institutet. Vi hittade olika vägar för att kunna få in folk. Vi försökte också hitta folk från olika håll, både geografiskt och i fråga om ämnesbakgrund. ${ }^{45}$

LS: Ja, folk som är intresserade av institutionsbyggen och starka forskningsmiljöer känner inte bara till Centret, utan ser det som ett slags humanistisk pionjärmiljö för något som sedan skulle komma. Det var inte så mycket snack om excellenscentrum på 80-talet. Så något av det som gjordes då blev sedan trendsättande för en slags vision på det forskningspolitiska området.

KH: Ja, både de här uppdragen och projektansökningar som vi hade framgång med blev viktiga. Det var väldigt betydelsefullt att det kom in pengar helt enkelt. Vi hade projektmedel hela tiden, och kunde på det sättet få in nya personer. Vi har väldigt aktivt odlat kontakten med myndigheter och verksamheter utanför universitetet. Och det ena har många gånger lett till det andra.

CS: Ja, som Rinkebyinstitutet, alltså Språkforskningsinstitutet i Rinkeby.

KH: Ja, det är intressant. Det var Stockholms stad som tog kontakt med universitetet för att diskutera möjligheterna att utveckla ett forskningscentrum i kommunal regi, som de kallade det för. Lars Cleve, som då var utbildningsledare vid fakulteten, kontaktade mig med detsamma och sa att »det här måste vi ju diskutera igenom». Det tog ett antal turer innan institutet kom till stånd. Men vi fick till stånd en verksamhet där det skulle bedrivas tillämpad, lokalt relevant forskning, och Centrum för tvåspråkighetsforskning skulle stå som vetenskaplig garant. Vi var med i deras styrelse och fick väldigt stort inflytande där, för vi var ju med och skrev stadgarna, tillsatte föreståndartjänster och så vidare.

CS: Ja, det var en väldigt spännande idé att ha en sådan här barn- och neighbourhood-inriktad forskningsinstitution. Det började ju bra med ett par tjänster och föreståndarskap. Monica Axelsson var den första föreståndaren, följd

\footnotetext{
44 Obondo, From Trilinguals to Bilinguals? (1996).

45 1994-2020 har 31 personer disputerat i tvåspråkighet vid Centrum för tvåspråkighetsforskning, Stockholms universitet.
} 
av Kari Fraurud. Marilyn Martin-Jones var också där ett år. Och bland annat Margaret Obondo var anställd som forskare.

LS: Jag skulle vilja gå tillbaka till ämnets tidiga utveckling och de impulser som drev på. Kenneth, du sa någonting tidigare om hur Hansegård »triggade Loman». Det är klart tänkvärt att Hansegårds idéer om halvspråkighet sporrade andra forskare att ge sig in i fältet. ${ }^{46}$ Hur ska man i så fall se på det som hände tidigare under 60-talet, då ett antal kunskapsproducenter började skriva kritiskt om statens minoritetsspråkpolitik i norra Sverige? Jag tänker till exempel på Nils Slunga och Hugo Tenerz. ${ }^{47}$ De hade en kritisk blick på de språkliga orättvisor som statens hållning skapat. Var det någonting som mer renodlade språkvetare sedan kunde ösa ur?

KH: Jag tror att det var en yttring av den rörelse, ethnic revival, som på 60-talet mynnade ut i kritiken av assimilationspolitiken och av förtrycket av minoriteter. Språk blev en stark symbol i den diskussionen. Slunga och Tenerz hade ju en bakgrund i den miljön och kände på ett personligt plan till de negativa språkliga effekterna av assimilationspolitiken. Pratar vi om akademiker var Israel Ruong och Nils Erik Hansegård tidigt ute med att ifrågasätta. Det hade man inte gjort tidigare, eller det hade i varje fall inte fătt samma genomslag. I fråga om det här med stigmatisering och självbild så hade det länge funnits en acceptans av den officiella hållningen, också bland minoriteterna $\mathrm{i}$ Sápmi. Men sedan kom det en tid då man började ifrågasätta det från alla tänkbara håll. Det var ju inte heller ett akademiskt initiativ i den bemärkelsen, utan det var mer den sociologiska och historiska utvecklingen som var pådrivande. Det var inte heller så att fokus bara låg på språkfrågor.

LS: Jag tycker att det här tidsskedet är spännande. Det är ju strax före tidsskedet då Sverige blev ett invandringsland, när de gamla minoritetsgrupperna så att säga utökades med nya. Jag läste nyligen något om hur det tillsynes behövdes europeisk invandring för att Sverige skulle få upp ögonen för det faktum att Sverige redan hade minoriteter.

KH: Det är intressant det där, för liknande kommentarer har jag hört $\mathrm{i}$ många andra sammanhang, inte minst det samiska sammanhanget, »Sverige glömde ju bort att det redan fanns en minoritetsproblematik innan 70-talet». För att använda en term som jag fått från dig Linus: det är intressant med den

\footnotetext{
46 Utöver Loman (1974), se t.ex. Stroud, The concept of semilingualism (1978). För en analys av halvspråkighetsdebatten, se Salö \& Karlander (u.u.).

47 T.ex. Slunga, Staten och den finskspråkiga befolkningen i Norrbotten (1965), Tenerz, Folkupplysningsarbetet i Norrbottens finnbygd under förra hälften av 1900-talet jämte språkdebatten (1963).
} 
här piggyback-aspekten. ${ }^{48}$ I praktiken blev det nog en fördel att det fanns både inhemska minoritetsgrupper och invandrade minoritetsgrupper. Vardera gruppen kunde bygga på och hämta styrka i det som uppnåtts av den andra gruppen.

LS: Ett exempel är David Schwarz bok från 1966 som ju knyter ihop de här två perspektiven. ${ }^{49}$ En del av bidragen i den om handlar om de gamla historiska frågorna. Exempelvis skrev Hansegård ett kapitel om språkförhållanden i Tornedalen ${ }^{50}$ och Oksaar ett om tvåspråkighet bland ester i Sverige. ${ }^{51}$ Andra bidrag handlar om de migrationsfrågor som började dyka upp under 1960-talet, om hur Sverige borde hantera det som kallades »invandrarnas anpassningsproblem $\rangle^{52}$ och så vidare. Men hur såg den här spänningen ut i praktiken? Var det så att Sveriges befintliga tvåspråkighetssituation drev fram det här intresset eller var det så att tvåspråkighetsforskningen fick vind i seglen från »imerämnena $\aleph^{53}$ och från migrationsdiskursen mer allmänt?

KH: Jag tror att det beror på vilken del av tvåspråkighetsforskningen man tänker på.

CS: Tornedalsfinskan fanns redan på den akademiska kartan på 60-talet, i och med de hansegårdska inläggen.${ }^{54}$ Sedan togs den hållningen upp av andra, som till exempel Tove Skutnabb-Kangas.

KH: Jag tror att de två utvecklingarna var rätt så oberoende av varandra.

CS: Ja, delvis. Men tänk på när Tove Skutnabb-Kangas och Pertti Toukomaa var i Olofström och testade invandrade grundskoleelever. ${ }^{55}$ De kunde relatera det sammanhanget till den finska problematiken i Tornedalen, så som den formulerats ur den hansegårdska synvinkeln. Så i varje fall där fanns det ju en länk mellan intresset för invandrarungdomars tvåspråkighet och de inhemska minoriteternas tvåspråkighet. Och här har vi ju också den tydliga länken mel-

48 Avser tendensen att låta en diskurs rida på eller ta rygg på en annan. Se Salö, Language ideology and shifting representations of linguistic threats (2014).

49 Svenska minoriteter, red. av Schwarz (1966).

${ }^{50}$ Hansegård (1966).

${ }^{51}$ Oksaar, Tvåspråkigheten och invandrarna (1966).

52 T.ex. Schwarz, Utlänningarnas anpassningsproblem (1964).

${ }_{53}$ Dvs. internationell migration och etniska relationer. Se t.ex. Vem älskar imerforskningen?, red. av Olsson \& Rabo (2009), Salö (2020).

54 Wande, Tornedalsfinskan och dess särdrag (1982).

55 Toukomaa, Om finska invandrarelevers språkutveckling och skolframgång i den svenska grundskolan (1977), The Intensive Teaching of the Mother Tongue to Migrant Children at PreSchool Age, red. av Toukomaa \& Skutnabb-Kangas (1977). 
lan Hansegårds halvspråkighetsbegrepp och begreppet rinkebysvenska som senare lanserades av Ulla-Britt Kotsinas. ${ }^{56}$

LS: Kenneth, du nämnde någonting tidigare om att samhällsrelevans var någonting som diskuterades då Centret skulle bildas. Kan något sägas om beställningsuppdrag från myndighetsväsendet och den sortens frågor?

DK: Alltså frågor om tillämpad forskning, om utredningsuppdrag och policyunderlag, om kontaktytorna för den mer tillämpade sidan av tvåspråkighetsforskningen.

KH: Alltså, man behöver inte sätta likhetstecken mellan tillämpning och uppdrag från myndigheter och liknande. Vad vi har försökt göra hela tiden är att hitta teoretiskt intressanta frågor i sådana uppdrag - alltså grundforskningsfrågor som kan triggas av praktiska problemformuleringar. De kan ändå ha en tillämpad dimension, även om jag tycker att man skulle ställa ännu högre krav på tillämpad forskning än vad vi har gjort. Vi har inte alltid tittat på resultatens användbarhet $i$ alla led. Ibland blir det antaganden om att ifall det förhåller sig så här teoretiskt sett så borde det betyda detta för tillämpningen, till exempel i undervisningen eller så. Men det skulle man ju behöva undersöka i sin egen rätt. ${ }^{57}$

CS: Jag tror det har varit viktigt att kunna ha högt i tak och höga ambitioner i de här utredningsarbetena. Det har inte direkt varit fråga om beställningsarbeten. Det har gått att göra någonting mer vetenskapligt intressant av dem.

LS: Den insikten tycker jag mycket om. Man tenderar ju numera att tänka på den samhällstillvända sidan som om den bara vore någon slags demokratisk plikt som man gör lite vid sidan av. Men vad ni säger är ju egentligen att det finns en synergieffekt, så att det hela snarare fungerar som trappan i Lustiga huset på Gröna Lund: man vickar på kroppen och tar sig uppåt.

CS: Ja, men det har funnits en del uppdragsarbete av enkel beställningstyp, till exempel den typ av konsultarbete som en del utbildningsforskare hållit på med. Fast in, fast out - alltså ett slags fallskärmsarbete. Åka till Etiopien, åka runt i olika skolor och redan ha skrivit ungefär tre kapitel av rapporten innan man har stigit av planet. Sedan ut ur landet och lyfta arvode. Om man ska exemplifiera med vår egen verksamhet kan vi prata om vårt arbete om utbildning och flerspråkighet i Moçambique som huvudsakligen finansierades av

\footnotetext{
${ }^{56}$ Kotsinas, Rinkebysvenska - en dialekt? (1987), se Stroud, Rinkeby Swedish and semilingualism in language ideological debates (2004).

${ }^{57}$ Se t.ex diskussionen i Hyltenstam \& Abrahamsson, Comments on Stefka H. Marinova-Todd, D. Bradford Marshall and Catherine E. Snow's "Three Misconceptions about Age and L2 Learning" (2001).
} 
Sida, och vårt sakkunniguppdrag för Samerättsutredningen. Bland annat höll vi på med ett sexårigt projekt kring den sociala struktureringen av portugisiskan i Maputo, ${ }^{58}$ och det kom hela tiden påtryckningar från Sida om slutrapporter, om vad det fanns för policy issues och så vidare. Men vi höll ändå fast vid detta att det var nödvändigt att skapa den här forskningsmiljön vid INDE ${ }^{59}$ tillsammans med Eduardo Mondlane-universitetet. Det var viktig capacity building, en bas för lokala forskare som kunde ta sig an frågor om utbildning och flerspråkighet. Och det gick Sida med på så småningom. Vi märkte i och för sig inte av sådana svårigheter i Samerättsutredningen, ${ }^{60}$ utan där var det ganska tacksamt att jobba med de involverade juristerna. Men jag tror att det finns en inneboende spänning mellan forskare och byråkrater. Så det gäller att skapa sig utrymme. Det lyckades vi göra på ett eller annat sätt där och då. Jag tror inte det skulle vara lika enkelt idag.

KH: När vi arbetade med Samerättsutredningen hade vi ju dragningar om vad vi höll på med för hela utredningen vid flera tillfällen. Den reaktion vi ofta fick var att de tyckte frågorna om språkbyte och språkbevarande generellt var väldigt intressanta. På det sättet blev det också rätt så stor frihet för oss att gå vidare.

CS: Men det hade också kunnat bli så att folk kanske tyckt »vad är ni för några som kommer hit och ska hålla i den här utredningen? Ni är ju inte samer - ni är ju representanter för storsamhället». Och så vidare. Likaså i Moçambique.

KH: Ja, det är ju en intressant fråga som är relevant på många sätt.

DK: Ja, inte minst idag.

LS: På tal om utbildning och flerspråkighet. En del av det här kunskapsintressets utveckling hänger samman med att nya utbildningsämnen introducerades i det svenska skolsystemet. Jag tänker på svenska som andraspråk och modersmål. Där fanns det en slags arena för en viss typ av kunskap som fanns representerad vid Centret.

$\mathrm{KH}$ : Vad gäller utbildningsorienteringen inom tvåspråkighetsforskningen så kan man inte bara se det ur Centrets synvinkel, även om den i viss utsträckning har sina rötter där. Inger Lindberg, med forskarutbildning från Centret,

\footnotetext{
58 Stroud \& Gonçalves, Panorama do Português oral de Maputo 1, II och IV (1997a, 1997b, 2000), Gonçalves \& Stroud, Panorama do Português oral de Maputo V (2002).

${ }^{59}$ Instituto Nacional do Desenvolvimento da Educação, ung. Nationalinstitutet för utbildningsutveckling.

${ }^{60}$ Hyltenstam \& Stroud, Språkbyte och språkbevarande i ett internationellt perspektiv med särskilt beaktande av situationen för samiskan i Sverige (1990).
} 
blev professor i svenska som andraspråk i Göteborg, som var den första professuren i ämnet. Inom parentes ändrades senare benämningen på denna professur till flerspråkighet med Tommaso Milani som innehavare, också han med forskarutbildning från Centret. Det var ju också vid Göteborgs universitet som man skapade Institutet för svenska som andraspråk redan 1996. Inriktningen i Göteborg, under Ingers ledning, blev tydligt utbildningsinriktad. När hon därefter blev professor vid Institutionen för språkdidaktik, när Lärarhögskolan i Stockholm slogs samman med Stockholms universitet, utvecklades den utbildningsinriktade flerspråkighetsforskningen starkt även i Stockholm, inte minst med forskning kring språkundervisning i relation till ämnesinlärning som Monica Axelsson har stått för, också hon professor vid Institutionen för språkdidaktik och med forskarutbildning från Centret.

LS: På flera sätt har den kunskapsproduktion som skett i samband med myndighetsuppdragen lett till vidare två- eller flerspråkighetsforskning. Vad har ni för tankar om detta?

KH: Får jag bara ta ett litet steg tillbaka innan vi kommer in på det. Det är värt att nämna den språktypologiska inriktningen som tidigt fanns vid Centret, och som framför allt utgjorde kopplingen till lingvistiken i Stockholm. Språktypologen Åke Viberg anställdes vid Avdelningen för tvåspråkighetsforskning 1983. Det stora SUM-projektet ${ }^{61}$ som han ledde, och som bland andra Inger Lindberg och Monica Axelsson blev anställda i, var en beställning från Skolöverstyrelsen. Projektet handlade om andraspråksutveckling, delvis i ett språktypologiskt perspektiv - framför allt i Åke Vibergs egen forskning omkring semantiska fält och ordförråd, men också i Monica Axelssons avhandling ${ }^{62}$ som handlade om nominalfraser hos talare av spanska och polska. Andraspråksutveckling var också ämnet för Maria Bolanders forskning i projektet. Hon skrev om negationer i svenskan. ${ }^{63}$ Inger Lindberg var den som framför allt fokuserade på undervisningsmodeller genom sina studier av interaktion i klassrummet. ${ }^{64}$

DK: Just det. Ska vi gå tillbaka till frågan om vidare effekter av myndighetsuppdragen?

KH: Men det är ju så intressant, för trots att detta var initiativ från myndigheter så blev de så otroligt viktiga för vad som sedan hände. Arbetet med Samerättsutredningen ledde bland annat till att ett par projekt med inriktning

${ }^{61}$ Språkutveckling och undervisningsmodeller, 1984-1987.

62 Axelsson, Noun Phrase Development in Swedish as a Second Language (1994).

${ }_{63}$ Bolander, »Man kan studera inte så mycke» (1987).

${ }^{64}$ T.ex. Lindberg, Second Language Discourse in and out of Classrooms (1995). 
på samiska i samarbete med Umeå universitet, Sameskolstyrelsen och så småningom även Sametinget, bland annat ett projekt som ledde till Mikael Svonnis avhandling om förstaspråksutveckling hos samiska skolbarn. ${ }^{65}$ För att inte tala om vad Moçambique ledde till, för det ledde till hela din, Christophers, mångåriga verksamhet i Afrika och forskningen där, och din forskning vid Centret med inriktning på transnationella flerspråkighetsfrågor.

CS: Ja, vi knöt ju på den tiden ganska täta kontakter med Sida och startade en seminarieserie också. Vi samarbetade med Göteborgs universitet, med Tore Jansson som blev professor i afrikanska språk där 1997. Vi hade ett gemensamt Moçambiqueprojekt bland annat. Under tiden i Moçambique träffade jag Carol Benson, som kom till Centret så småningom när hennes Sida-kontrakt tog slut. Och så hade vi medel från Sida för institutionsutveckling. Vi hade ett par, tre projekt finansierade av Sida under 90-talet. Men visst, jag tänker också på nätverken med Kathleen Heugh och Peter Plüddemann i Sydafrika, som kom till under 90-talet. Sa de här statliga utrednings- och uppdragsuppgifterna har ju fallit på Centret just på grund av att det varit ett centrum för tvåspråkighetsforskning. Men det har inte stannat där. Det har skapats kontaktytor som sedan vidareutvecklats. Och det tycker jag är något som skiljer sig från många svenska institutioner. Så där kan man nog se två orsaker till att Centret blivit en så fruktbar miljö som det varit.

DK: Och de är alltså?

CS: Ja, den ena är uppdragsforskningen - den tillämpade skolforskningen och sådant - där det samtidigt funnits väldigt stort utrymme för personliga intressen och teoretiska frågeställningar. Det andra är forskningspolitiken, med stora anslag där forskare får betalt för sin forskning. Alltså VR-projekt, Riksbankens Jubileumsfond, som inte finns på alla håll i världen. Som här på centret i Kapstaden. ${ }^{66}$ Här beror det väldigt mycket på vem som råkar vara här, på vem som vill engagera sig i flerspråkighetsforskning. Men i det svenska sammanhanget har det funnits samhällsinstitutioner som har velat ha svar på vissa frågor. Det är nog en typiskt svensk eller nordisk företeelse.

KH: Ja, i det sammanhanget har ju det varit väldigt viktigt att den fasta strukturen har funnits där. Om man jämför Centret med många centra runt om i världen som heter något med flerspråkighet, så är de ju för det mesta organiserade kring intressekonstellationer. Den fasta strukturen är viktig, så att man

\footnotetext{
${ }^{65}$ Svonni, Samiska skolbarns samiska (1993).

${ }^{66}$ Centre for Multilingualism and Diversities Research, University of the Western Cape, Sydafrika.
} 
vet att från år till år så finns det en långsiktig utveckling och permanent verksamhet där. Det tror jag har varit en viktig aspekt på detta.

LS: Ändå tycks Centret ha bibehållit en språkvetenskaplig karaktär.

CS: Ja, det berodde ju naturligtvis mycket på att Kenneth rekryterades till Centrum för tvåspråkighetsforskning, på att han hade den forskningsbakgrund han hade.

KH: Ja, det var också en uttalad policy från vår fakultet. Det betonades att Centret skulle ha en språkvetenskaplig inriktning. Det hade klart att göra med att Centret inrättades vid den humanistiska fakultetens språkvetenskapliga sektion. När vi hade hållit på några år så fick vi särskilda öronmärkta statliga medel och då anställde vi Åke Viberg, som forskade om andraspråksinlärning. Men även Lenore Arnberg med bakgrund i psykologi och pedagogik, som hade en forskningsinriktning mot barns tvåspråkiga utveckling. Vi började också resonera om äldre tvåspråkiga individer. Vi hade en idé om att man borde täcka in hela livsförloppet, forska om tvåspråkighet under olika skeden i livet. ${ }^{67}$ På området tolkning och översättning fick vi 1987 en forskarassistenttjänst förlagd till dåvarande Avdelningen för tvåspråkighetsforskning med Birgitta Englund Dimitrova som första innehavare, följd av Sarah Williams 1993. Tolk- och översättarinstitutet, TÖI, inrättades 1986, men hade inte på många år i uppdrag att bedriva forskning, vilket var skälet till att forskarassistenttjänsten kopplades till Centret.

DK: Hur var det i Göteborg på den tiden? Med Gunnar Tingbjörn och de andra som var där?

KH: När det gäller Göteborg så var det dels Gunnar Tingbjörn och hans forskning om flerspråkighet i ungdomsskolan, samt några andra forskare som Anders Börje Andersson och Kerstin Nauclér ${ }^{68}$ som bedrev forskning omkring tvåspråkighet i förskolan; Roger Källström ${ }^{69}$ hörde också till den gruppen. Dels var det Sally Boyd på lingvistiken som skrev sin avhandling ${ }^{70}$ om språkval bland tvåspråkiga barn. Hon var också forskarassistent vid CEIFO,$^{71}$ som vi hade en del samarbeten med, bland annat en gemensam seminarieserie. I

${ }^{67}$ Hyltenstam, I livets olika skeden (1989), Bilingualism Across the Lifespan, red. av Hyltenstam \& Obler (1989). Denna inriktning har på senare år fått genomslag i verksamheten vid Senter for flerspråklighet (Multiling), Universitetet i Oslo.

${ }_{68}$ Andersson \& Nauclér, Språkmiljö och språkinlärning (1987).

${ }^{69}$ Källström, Kongruens i svenskan (1990).

70 Boyd, Language Survival (1985).

${ }^{71}$ Centrum för forskning om internationell migration och etniska relationer, Stockholms universitet. 
Göteborg fanns på andraspråksområdet också den svenska delen av ESF ${ }^{72}$-projektet EALA, Ecology of Adult Language Acquisition, med Jens Allwood som ledare. ${ }^{73}$ Vid Linköpings universitet, Tema: Kommunikation, fanns flera bidrag till nya riktningar inom tvåspråkighetsforskningen, bland annat med Lennart Gustavssons $^{74}$ avhandling på andraspråksområdet, Cecilia Wadensjös ${ }^{75}$ inom tolkningsforskningen och Jakob Cromdals ${ }^{76}$ om kodväxling i barns kommunikation.

\section{LS: Och de två gamla lärdomsstäderna?}

KH: I Lund blev Gisela Håkansson ${ }^{77}$ och senare Marianne Gullberg ${ }^{78}$ de ledande andraspråksforskarna. Sedan Suzanne Schlyter flyttade från lingvistiken vid Stockholms universitet och blev professor i franska utvecklades forskningen om främmandespråksinlärning där med Jonas Granfelt som senare huvudaktör på det området. Denna forskning har haft en tydlig koppling till främmandespråksinlärningsforskningen i franska och spanska vid Stockholms universitet under ledning av Inge Bartning respektive Lars Fant. I Uppsala var Finsk-ugriska institutionen en viktig aktör i flerspråkighetsforskningen. Erling Wande var där ledare av projekt omkring finskan i Sverige, och bland annat Raimo Raag publicerade arbeten om estniskan i Sverige. ${ }^{79}$ Denna forskningsmiljö och den sociolingvistiska Avdelningen för forskning om utbildning och modern svenska, FUMS, var också ramen för Jarmo Lainios avhandling om finskan i Sverige. ${ }^{80}$

CS: Och Leena Huss.

KH: Ja, hennes avhandling ${ }^{81}$ var direkt tvåspråkighetsinriktad. Den handlade om principen hos föräldrar att koppla ett språk till en person i tvåspråkig barnuppfostran.

DK: Jag skulle vilja gå tillbaka till ett annat ämne: den internationella orienteringen. Vi har varit inne på den vid några tillfällen, med Moçambique, med Sida, med Marilyn Martin-Jones och så vidare. Och du, Kenneth, studerade väl med Pit Corder i Edinburgh. Hela den orienteringen är också tydlig i några

\footnotetext{
${ }_{72}$ European Science Foundation.

73 Allwood, Strömqvist \& Voionmaa, Ecology of adult language acquisition (1983).

74 Gustavsson, Language Taught and Language Used (1988).

75 Wadensjö, Interpreting as Interaction (1992).

${ }^{76}$ Cromdal, Code-Switching for All Practical Purposes (2000).

77 Håkansson, Teacher Talk (1987).

${ }^{78}$ Gullberg, Gesture as a Communication Strategy in Second Language Discourse (1998).

79 Raag, Lexical Characteristics in Swedish Estonian (1982).

${ }^{80}$ Lainio, Spoken Finnish in Urban Swedish (1989).

${ }^{81}$ Huss, Simultan tvåspråkighet i svensk-finsk kontext (1991).
} 
utgivna volymer. Om man exempelvis kollar i Progression and Regression in Language ${ }^{82}$ är det rätt imponerande vilka namn som dyker upp. Det finns bidrag av bland annat Peter Mühlhäusler, Jane Hill, Loraine Obler, Mike Long, Anne Holmen, Don Kulick.

CS: Centret hade också afrikanska forskare under längre forskningsvistelser, som Mubanga Kashoki från Zambia. Han som var med i det stora Ford Foundation-projektet om kartläggningen av afrikanska språk. En legend, faktiskt.

KH: Och Sammy Chumbow från Kamerun.

DK: Man kan också titta i andra riktningar. Ett annat exempel är Centrets tidigare doktorander från södra Afrika. Jag tänker på Kathleen Heugh, Caroline Kerfoot, Peter Plüddemann och Manuel Guissemo, som kommit till Stockholm och sedan rört sig vidare till andra ställen, eller blivit kvar. Man kan kanske säga att de inte bara har bidragit till flerspråkighetsforskningens internationella frammarsch utan också fört in stockholmska perspektiv i den.

KH: Plus Japan om man går längre tillbaka i tiden, med Emiko Yukawa. ${ }^{83}$

LS: Ja, jag har en liten sak om det här med att balansera vad man kan kalla inhemskt engagemang och ansvarskänsla med internationell eminens. Det är lätt att bli nostalgisk när man går in i Centrets kopieringsrum och ser alla ROTrapporter. ${ }^{84}$ De kommer från en tid då man kunde publicera sig lite som man ville. Man har en känsla av att det hänt något sedan dess, att det gått upp för folk vad som är värt vad på ett CV. Det har blivit större fokus på att få in artiklar i internationella topptidskrifter, vilket ju är bra, men man har då fått kompromissa med en del annat. Det har till exempel varit några tillfällen då Sveriges Radio haft program om frågor som är centrala för Centrets verksamhet men där ingen från Centret medverkat. Då kommer man in på frågan om hur man återbefolkar de här betydelsefulla arenorna, men utan att tumma på det vetenskapliga anspråket. Man måste på något sätt stå med ett ben i vetenskapen och ett utanför för att få detta att funka. ${ }^{85}$

CS: Det hänger också ihop med punkten som nämndes före, med internationalisering och h-index och allt vad det är. Man ska publicera. Då blir det vissa uppdrag som man inte kan ta sig an som proffsakademiker i karriären. Jag

\footnotetext{
82 Progression and Regression in Language, red. av Hyltenstam \& Viberg (1993).

83 Yukawa, L1 Japanese Attrition and Regaining (1997).

${ }^{84}$ Rapporter om tvåspråkighet, utgivna av Centrum för tvåspråkighetsforskning med start 1984. För närvarande vilande.

${ }^{85}$ Se Bourdieu, Texter om de intellektuella (1992).
} 
menar, working paper-serierna gav ju lite utrymme för någon slags flum, eller efterforskande eller ja, de gav ju uttryck för något annat.

LS: Min förståelse för 90-talet är att ni lyckades bibehålla den här samhällstillvändheten samtidigt som ni avancerade internationellt. Under samma period som ni höll på med SOU:er och hängde i förorten fortsatte ni att utveckla en internationellt stark forskningsmiljö. Det är rätt intressant, för man ser många miljöer som får slagsida åt antingen det ena eller åt det andra hållet. På något sätt känns det som att balansen mellan forskning och samverkan var väldigt jämn under en tid på Centret. Ligger det någonting i det?

$\mathrm{KH}$ : Ja, det är lätt att det bara blir samhällsengagemang och ingenting vetenskapligt att stå på. Nej, men det är klart att vi haft intensiva internationella kontakter samtidigt som vi haft ett tydligt intresse för samhällsfrågor som kan hämta kunskap från vårt fält. Det är väl det som har lett till balansen, antar jag.

DK: Jag tror vi måste börja runda av här. Några avslutande ord? Finns det något att tillägga om ämnets uppkomst och utveckling? Finns det något mer som är viktigt att framhålla om bakgrunden till dagens forskning om flerspråkighet?

KH: Ja, egentligen finns det massor att tillägga. När man tänker över vad vi kommit in på, så är det ju allra främst skeendena under de två sista decennierna av 1900-talet. Vi har ju mest försökt kartlägga bakgrunden till hur tvåoch flerspråkighetsforskningen ser ut i Sverige idag. Men så ofantligt mycket har hänt på området under de två decennier som ligger närmast bakom oss. Det har genomförts en närmast oöverblickbar mängd forskning på i stort sett alla universitet och högskolor i landet. Den forskningsöversikt som vi genomförde i VR:s regi $2012^{86}$ skulle behöva uppdateras nu och kompletteras med flera ingående forskningsområden som vi där var tvungna att lämna utanför, t.ex. forskning om de nationella minoritetsspråken i Sverige, tvåspråkighet för döva och tolkning och översättning.

CS: Ja, det går ju inte att täcka in allt i ett sådant här samtal. Men jag tror att vi lyckats peka på värdet av institutionell stabilitet för en forskningsinriktnings utveckling. Om det är något vi missat så är det att ta upp bakgrunden till den psyko- och neurolingvistiska inriktning som idag är bland det internationellt mest uppmärksammade i svensk flerspråkighetsforskning (se Abrahamsson \& Bylund i detta temanummer). Centrets forskning på 1980-talet om tvåspråkig-

${ }^{86}$ Hyltenstam, Axelsson \& Lindberg (2012). 
het hos dementa ${ }^{87}$ blev en slags inkörsport till avhandlingar om attrition. ${ }^{88} \mathrm{Och}$ forskning inom ett annat beställningsarbete från Skolöverstyrelsen om gymnasieelevers svenska ${ }^{89}$ blev första steget in i Centrets forskning om ålder och slutlig behärskningsnivå i andraspråksinlärning. ${ }^{90}$

KH: En annan reflektion man kan göra över vårt samtal är att det rör sig väldigt mycket omkring den roll Centrum för tvåspråkighetsforskning har och har haft i fältets utveckling. Detta kan eventuellt uppfattas som omotiverat och inte så lite självhävdande med tanke på att Centret är eller har varit den viktigaste institutionella hemvisten för oss alla fyra, men jag vill ändå säga att det inte bara är av självgoda skäl vi låtit samtalet få detta innehållsfokus. Vad vi velat förmedla är framför allt vad det kan betyda för ett forskningsområdes utveckling att det existerar en formaliserad institutionsbildning och vad omständigheter som avnämarkontakter, internationella samarbeten, rekrytering av forskningspersonal och inrättandet av forskarutbildning på området kan betyda. Det här har ju varit ett rätt så spontant samtal, och det är självklart så att vi inte alls berört många av de viktiga forskningsinsatser som genomförts vid flera universitet under det senaste halvseklet. Men det var naturligtvis inte heller vår avsikt att försöka ge en heltäckande bild. Det får vänta tills någon ger sig på att skriva nästa forskningsöversikt över svensk två- och flerspråkighetsforskning.

\section{Litteratur}

Abrahamsson, Niclas \& Hyltenstam, Kenneth, 2009: Age of onset and nativelikeness in a second language: Listener perception versus linguistic scrutiny. I: Language Learning 58(2). S. 249-306.

Allwood, Jens, Strömqvist, Sven \& Voionmaa, Karlo, 1983: Ecology of adult language acquisition. A psycholinguistic research project. Gothenburg Papers in Theoretical Linguistics 45, Göteborgs universitet.

Andersson, Anders-Börje \& Nauclér, Kerstin, 1987: Språkmiljö och språkinlärning. Slutrapport från projektet Hemspråket i förskolan. SPRINS-rapport 38, Göteborgs universitet.

${ }^{87}$ Hyltenstam \& Stroud, Bilingualism in Alzheimer's dementia (1989).

${ }^{88}$ Yukawa (1997), Bylund, Age Differences in First Language Attrition (2008), Lubińska, Förstaspråksattrition hos vuxna (2011).

${ }^{89}$ Hyltenstam, Non-native features of near-native speakers (1992), Stroud, Literacy in a second language (1988).

90 Abrahamsson \& Hyltenstam, Age of onset and nativelikeness in a second language (2009). 
Axelsson, Monica, 1994: Noun Phrase Development in Swedish as a Second Language. (Diss. in Bilingualism 1.) Stockholms universitet.

Bayly, Christopher A, Beckert, Sven, Connelly, Matthew, Hofmeyr, Isabel, Kozol Wendy \& Seed, Patricia, 2006: AHR Conversation: On Transnational History. I: The American Historical Review 111(5). S. 1441-1464.

Berggren, Henrik, 2010: Underbara dagar framför oss: en biografi över Olof Palme. Stockholm: Norstedts.

Bilingualism Across the Lifespan. Aspects of Acquisition, Maturity, and Loss, red. av Kenneth Hyltenstam \& Loraine K. Obler. Cambridge: Cambridge University Press 1989.

Bilingualism: A Social Approach, red. av Monica Heller. London: Palgrave Macmillan 2007.

Bolander, Maria, 1987: »Man kan studera inte så mycke»: om placering av negation och adverb i vuxna invandrares svenska. SUM-rapport 5, Stockholm universitet.

Bourdieu, Pierre, 1992: Texter om de intellektuella. Stockholm: Symposion.

Boyd, Sally, 1985: Language Survival: A Study of Language Contact, Language Shift and Language Choice in Sweden. (Gothenburg Monographs in Linguistics 6.) Göteborgs universitet.

Bylund, Emanuel, 2008: Age Differences in First Language Attrition. A Maturational Perspective. (Diss. in Bilingualism 17.) Stockholms universitet.

Cromdal, Jakob, 2000: Code-switching for all practical purposes: Bilingual organization of children's play. (Linköping Studies in Arts and Science 223.) Linköpings universitet.

Dornič, Stanislav, 1978: The Bilingual's Performance: Language Dominance, Stress, and Individual Differences. Reports from the Institute of Applied Psychology 67, Stockholms universitet.

Error Analysis, Contrastive Linguistics, and Second Language Learning: Papers from the 6th International Congress of Applied Linguistics, red. av Gerhard Nickel \& Dietrich Nehls. Heidelberg: Groos 1981.

Faust, Drew, Hartog, Hendrik, Hollinger, David A., Iriye, Akira, Nelson Limerick, Patricia, Irvin Painter, Nell, Roediger, David, Ryan, Mary \& Taylor, Alan, 2003: Interchange: The practice of history. I: The Journal of American History 90(2). S. 576-611.

Flerspråkighet - en forskningsöversikt, red. av Kenneth Hyltenstam, Monica Axelsson \& Inger Lindberg. (Vetenskapsrådets rapportserie 5:2012.) Stockholm: Vetenskapsrådet 2012.

Flerspråkighet, litteracitet och multimodalitet, red. av Åsa Wedin \& Christina Hedman. Lund: Studentlitteratur 2013.

Främmandespråksundervisning och översättarutbildning, red. av Kenneth Hyltenstam. Lund: Liber 1981.

Gonçalves, Perpétua \& Stroud, Christopher, 2002: Panorama do Português oral de Maputo, V. Vocabulário básico do Português. Dicionário de regências. Maputo: INDE. 
Gullberg, Marianne, 1998: Gesture as a Communication Strategy in Second Language Discourse: A Study of Learners of French and Swedish. (Travaux de l'Institut de Linguistique de Lund 35.) Lund: Lund University Press.

Gustavsson, Lennart, 1988: Language Taught and Language Used. Dialogue Processes in Dyadic Lessons of Swedish as a Second Language Compared with Non-Didactic Conversations. (Linköping Studies in Arts and Science 18.) Linköpings universitet.

Hansegård, Nils Erik, 1966: Finskt i Tornedalen, en glömd minoritet. I: Svenska minoriteter, red. av David Schwarz. Stockholm: Aldus/Bonnier. S. 162-182.

Hansegård, Nils Erik, 1968: Tvåspråkighet eller halvspråkighet? Stockholm: Aldus/ Bonnier.

Hansegård, Nils-Erik, 1990: Den norrbottenfinska språkfrågan. En återblick på halvspråkighetsdebatten. (Uppsala Multiethnic Papers 19.) Uppsala universitet.

Harris, Randy, 1993: The Linguistics Wars. Oxford: Oxford University Press.

Haugen, Einar, 1956: Bilingualism in the Americas: A Bibliography and Research Guide. I: Publications of the American Dialect Society 26. Drawer: University of Alabama Press.

Heller, Monica, 2007: Bilingualism as ideology and practice. I: Bilingualism: A social Approach, red. av Monica Heller. New York: Palgrave. S. 1-22.

Huck, Geoffrey \& Goldsmith, John, 1995: Ideology and Linguistic Theory: Noam Chomsky and the Deep Structure Debates. London: Routledge.

Hugentobler, Jacob, 1928: Die mehrsprachige Schweiz. I: Nation und Staat 1. S. 914929.

Huss, Leena, 1991: Simultan tvåspråkighet i svensk-finsk kontext. (Studia Uralica Upsaliensia 21.) Uppsala universitet.

Hyltenstam, Kenneth, 1989: I livets olika skeden. I: Invandrare och minoriteter 1. S. 34-36.

Hyltenstam, Kenneth, 1992: Non-native features of near-native speakers. On the ultimate attainment of childhood L2 learners. I: Cognitive Processing in Bilinguals, red. av Richard J. Harris, Amsterdam: Elsevier. S. 351-368.

Hyltenstam, Kenneth \& Abrahamsson, Niclas, 2001: Comments on Stefka H. Marinova-Todd, D. Bradford Marshall and Catherine E. Snow's »Three Misconceptions about Age and L2 Learning». Age and L2 learning: the hazards of matching practical »implications» with theoretical »facts». TESOL Quarterly 35(1). S. 151-170.

Hyltenstam, Kenneth \& Stroud, Christopher, 1989: Bilingualism in Alzheimer's dementia: two case studies. I: Bilingualism Across the Lifespan. Aspects of Acquisition, Maturity, and Loss, red. av Kenneth Hyltenstam \& Loraine K. Obler. Cambridge: Cambridge University Press. S. 202-226.

Hyltenstam, Kenneth \& Stroud, Christopher, 1990: Språkbyte och språkbevarande i ett internationellt perspektiv med särskilt beaktande av situationen för samiskan i Sverige: underlagsrapport. (Samerättsutredningen SOU 1990:84.) Stockholm: Allmänna förlaget.

Håkansson, Gisela, 1987: Teacher Talk: How Teachers Modify their Speech when Addressing Learners of Swedish as a Second Language. (Travaux de l'institut de linguistique de Lund 20.) Lund: Lund University Press. 
Jaakkola, Magdalena, 1973: Språkgränsen: en studie i tvåspråkighetens sociologi. Stockholm: Aldus/Bonnier.

Johansson, Henning, 1975: Samernas språk och kultur: en intervjuundersökning rörande kulturella, sociala och psykologiska frågor. Umeå universitet.

Karlander, David, 2018: The linguistic prerequisites for cultural analysis: Lars Levander's reocentric ethnographies of Swedish peasant life and language. I: Signs and Society 6(3). S. 504-530.

Koerner, E. F. Konrad, 2002: Toward a History of American Linguistics. New York: Routledge.

Kotsinas, Ulla-Britt, 1978: Rinkebysvenska - en dialekt? I: Svenskans beskrivning 16, red. av Per Linell, Viveka Adelsvärd, Torbjörn Nilsson \& Per A. Petersson. Linköpings universitet. S. 264-278.

Källström, Roger, 1990: Kongruens i svenskan. (Nordistica Gothoburgensia 16.) Göteborgs universitet.

Lainio, Jarmo, 1989: Spoken Finnish in Urban Swedish. (Uppsala Multiethnic Papers 15.) Uppsala universitet.

Leopold, Werner F., 1939-1949: Speech Development of a Bilingual Child. A Linguist's Record, Vol 1-4. Evanston: Northwestern University.

Levelt, Willem J., 2013: A History of Psycholinguistics: The Pre-Chomskyan Era. Oxford: Oxford University Press.

Lindberg, Inger, 1995: Second Language Discourse in and out of Classrooms. (Dissertations in Bilingualism 2.) Stockholm universitet.

Lubińska, Dorota, 2011: Förstaspråksattrition hos vuxna. Exemplet polsktalande i Sverige. (Dissertations in Bilingualism 21.) Stockholms universitet.

Löfgren, Horst \& Ouvinen-Birgerstam, Pirjo, 1980: Försök med en tvåspråkig modell för undervisning av invandrarbarn. Pedagogiska rapporter 22, Lunds universitet.

Malmberg, Bertil, 1945: Ett barn byter språk. Drag ur en fyraårig finsk flickas språkliga utveckling. I: Nordisk tidskrift för vetenskap 21. S. 170-181.

Malmberg, Bertil, 1971: Språkinlärning. En orientering och ett debattinlägg. Stockholm: Aldus/Bonniers.

Malmberg, Bertil, 1991: Histoire de la linguistique de Sumer à Saussure. Paris: PUF.

Meier, Gabriela Sylvia, 2017: The multilingual turn as a critical movement in education: assumptions, challenges and a need for reflection. I: Applied Linguistics Review 8(1). S. 131-161.

Mägiste, Edith, 1982: Speed and Memory Performance in Bilinguals. (Diss. in Psychology.) Stockholms universitet.

Nordens språk som målspråk: forskning och undervisning, red. av Kenneth Hyltenstam \& Katrin Maandi. Stockholms universitet 1983.

Obondo, Margaret, 1996: From Trilinguals to Bilinguals? A study of the Social and Linguistic Consequences of Language Shift on a Group of Urban Luo Children in Kenya. (Diss. in Bilingualism 3.) Stockholms universitet.

Oksaar, Els, 1966: Tvåspråkigheten och invandrarna. I: Svenska minoriteter, red. av David Schwarz. Stockholm: Aldus/Bonnier. S. 68-83 
Oksaar, Els, 1970: Zum Spracherwerb des Kindes in zweisprachiger Umgebung. Folia Linguistica 4(3-4). S. 330-358.

Papers in Contrastive Linguistics and Language Testing, red. av Stig Johansson. Lund: CWK Gleerup 1975.

Progression and Regression in Language: Sociocultural, Neuropsychological and Linguistic Perspectives, red. av Kenneth Hyltenstam \& Åke Viberg. Cambridge: Cambridge University Press 1993.

Pötzl, Otto, 1930: Aphasie und Mehrsprachigkeit. I: Zeitschrift für die gesamte Neurologie und Psychiatrie 124. S. 145-162.

Raag, Raimo, 1982: Lexical Characteristics in Swedish Estonian. (Studia Uralica et Altaica Upsaliensia 13.) Uppsala universitet.

Readings in Aphasia in Bilinguals and Polyglots, red. av Michel Paradis. Quebec: Didier 1983.

Ronjat, Jules, 1913: Le développement du langage observé chez un enfant bilingue. Paris: Champion.

Rūķe-Draviṇa, Velta, 1967: Mehrsprachigkeit im Vorschulalter. Travaux de l'Institut de phonétique de Lund 5, Lunds universitet.

Salö, Linus, 2014: Language ideology and shifting representations of linguistic threats: A Bourdieusian re-reading of the conceptual history of domain loss in Sweden's field of language planning. I: English in Nordic Universities: Ideologies and Practices, red. av Anna Kristina Hultgren, Frans Gregersen \& Jacob Thøgersen. Amsterdam: John Benjamins. S. 83-110.

Salö, Linus, 2020: Invandrarutredningen och 1970-talets språkideologiska omvälvningar: Till frågan om modersmålsundervisningens kunskapssociologi. I: Rapporter från Forskningsgruppen för utbildnings- och kultursociologi 62, Uppsala universitet.

Salö, Linus \& Karlander, David, under utgivning: The travels of semilingualism: Itineraries of ire, impact, and infamy. I: Multilingualism and Linguistic Citizenship: Education, Narrative and Episteme, red. Quentin Williams, Ana Deumert \& Tommaso Milani. Clevedon: Multilingual Matters.

Schwarz, David, 1964: Utlänningarnas anpassningsproblem. I: DN, 28 oktober. S. 4.

Skutnabb-Kangas, Tove, 1975: Om tvåspråkighet och skolframgång. Åbo: Svenska litteratursällskapets i Finland nämnd för samhällsforskning.

Slunga, Nils, 1965: Staten och den finskspråkiga befolkningen i Norrbotten. Luleå: Tornedalica.

Språk och samhälle 2, red. av Bengt Loman. Lund: Liber 1974.

Språkmöte: svenska som främmande språk, hemspråk, tolkning, red. av Kenneth Hyltenstam. Lund: Liber 1981.

Stedje, Astrid \& af Trampe, Peter, 1979: Språk, individer och grupper - en översikt av tvåspråkighetens huvudfrågor. I: Tvåspråkighet: föredrag vid det andra nordiska tvåspråkighetssymposiet, red. av Astrid Stedje \& Peter af Trampe. Stockholm: Akademilitteratur. S. 7-50.

Stroud, Christopher, 1978: The concept of semilingualism. I: Lund Working Papers in Linguistics 16. S. 154-172. 
Stroud, Christopher, 1988: Literacy in a second language. A study of text construction in near-native speakers of Swedish. I: Bilingualism and the Individual, red. av Anne Holmen, Elisabeth Hansen, Jørgen Gimbel \& Jens Norman Jørgensen. Clevedon: Multilingual Matters. S. 235-251.

Stroud, Christopher, 2004: Rinkeby Swedish and semilingualism in language ideological debates: A Bourdieuean perspective. I: Journal of Sociolinguistcs 8(2). S. 196-214.

Stroud, Christopher \& Gonçalves, Perpétua, 1997a: Panorama do Português oral de Maputo, I. Objectivos e métodos. Maputo: INDE.

Stroud, Christopher \& Gonçalves, Perpétua, 1997b: Panorama do Português oral de Maputo, II. A constução de um banco de "erros". Maputo: INDE.

Stroud, Christopher \& Gonçalves, Perpétua, 2000: Panorama do Português oral de Maputo, IV. Vocabulário básico do Português (espaço, tempo e quantidade): Contextos e Prática Pedagógica. Maputo: INDE.

Svenska i invandrarperspektiv: kontrastiv analys och språktypologi, red. av Kenneth Hyltenstam. Lund: Liber 1979.

Svenska minoriteter, red. av David Schwarz. Stockholm: Aldus/Bonnier 1966.

Svenska som andraspråk - i forskning, undervisning och samhälle, red. av Kenneth Hyltenstam \& Inger Lindberg. Lund: Studentlitteratur 2013.

Svonni, Mikael, 1993: Samiska skolbarns samiska: en undersökning av minoritetsspråksbehärskning i en språkbyteskontext. (Umeå studies in the Humanities 113.) Umeå universitet.

Tenerz, Hugo, 1963: Folkupplysningsarbetet i Norrbottens finnbygd under förra hälften av 1900-talet jämte språkdebatten. Stockholm: Seelig \& Co.

The Intensive Teaching of the Mother Tongue to Migrant Children at Pre-School Age, red. av Pertti Toukomaa och Tove Skutnabb-Kangas. Tampere: Tampereen yliopisto 1977.

The Early Days of Sociolinguistics, red. av Christina Bratt Paulston \& Richard Tucker, 2010. Dallas: SIL International.

The Multilingual Turn: Implications for SLA, TESOL and Bilingual Education, red. av Stephen May. New York: Routledge 2014.

Tingbjörn, Gunnar, 1986: Skolan som resursförvaltare I: Invandrarspråken - ratad resurs?, red. av Cecilia Wadensjö. Stockholm: Forskningsrådsnämnden. S. 25-39.

Toukomaa, Pertti, 1977: Om finska invandrarelevers språkutveckling och skolframgång i den svenska grundskolan: resultat av undersökningar i Olofström och Göteborg. Ceifo, Stockholms universitet.

Vem älskar imerforskningen? En jubileumsskrift för CEIFO, red. av Erik Olsson \& Annika Rabo. Ceifo, Stockholms universitet 2009.

Wacquant, Loïc, 1989: Towards a reflexive sociology: A workshop with Pierre Bourdieu. I: Sociological Theory 7(1). S. 26-63.

Wadensjö, Cecilia, 1992: Interpreting as Interaction: On Dialogue-Interpreting in Immigration Hearings and Medical Encounters. (Linköping Studies in Arts and Science 83.) Linköpings universitet. 
Wande, Erling, 1982: Tornedalsfinskan och dess särdrag. I: Finska språket i Sverige. Finska språket i Tornedalen, Stockholm: Föreningen Norden, Kulturfonden för Sverige och Finland och Finn-Kirja S. 40-73.

Weinreich, Uriel, 1953: Languages in Contact: Findings and Problems. New York: Linguistic Circle of New York.

Yukawa, Emiko, 1997: L1 Japanese Attrition and Regaining: Three Case Studies of Two Early Bilingual Children. (Diss. in Bilingualism 4.) Stockholms universitet. 